\title{
GENERAL-EQUILIBRIUM APPROACHES TO THE MULTINATIONAL FIRM: A REVIEW OF THEORY AND EVIDENCE
}

\author{
James R. Markusen \\ Keith E. Maskus \\ Working Paper 8334 \\ http://www.nber.org/papers/w8334 \\ NATIONAL BUREAU OF ECONOMIC RESEARCH \\ 1050 Massachusetts Avenue \\ Cambridge, MA 02138 \\ June 2001
}

This paper has been prepared for the volume: Harrigan, James (editor), Handbook of International Trade, London: Basil Blackwell. First presentation was at the National Bureau of Economic Research, March 16-17, 2001. The views expressed herein are those of the authors and not necessarily those of the National Bureau of Economic Research.

(C) 2001 by James R. Markusen and Keith E. Maskus. All rights reserved. Short sections of text, not to exceed two paragraphs, may be quoted without explicit permission provided that full credit, including $(\mathrm{C}$ notice, is given to the source. 
General-Equilibrium Approaches to the Multinational Firm:

A Review of Theory and Evidence

James R. Markusen and Keith E. Maskus

NBER Working Paper No. 8334

June 2001

JEL No. F13, F23

\begin{abstract}
$\underline{\text { ABSTRACT }}$
Beginning in the early 1980 s, theoretical analyses have incorporated the multinational firm into the microeconomic, general-equilibrium theory of international trade. Recent advances indicate how vertical and horizontal multinationals arise endogenously as determined by country characteristics, including relative size and relative endowment differences, and trade and investment costs. Results also characterize the relationship between foreign affiliate production and international trade in goods and services. In this paper, we survey some of this recent work, and note the testable predictions generated in the theory. In the second part of the paper, we examine empirical results that relate foreign affiliate production to country characteristics and trade/investment cost factors. We also review findings from analyses of the pattern of substitutability or complementarity between trade and foreign production.
\end{abstract}

James R. Markusen

Department of Economics

University of Colorado

Boulder, CO 80309-0256

and NBER

james.markusen@colorado.edu
Keith E. Maskus

Department of Economics

University of Colorado

Boulder, CO 80309-0256

keith.maskus@colorado.edu 


\section{1. $\quad$ Introduction}

Both theoretical and empirical studies of the activities of multinational firms cover a wide range of topics. Often, the questions asked and analytical avenues taken draw from quite different sub-areas of economic theory. Some approaches are more the stuff of macroeconomics, some relate to general-equilibrium trade theory, and some more closely relate to the theory of the firm, the latter using the tools of game and information theories.

This paper will concentrate on the general-equilibrium trade-theory view of the multinational firm, reviewing recent theoretical and empirical analysis. This is no way suggests that macroeconomic and theory-of-the-firm approaches to the multinational are unimportant or uninteresting. It is rather that the trade-theory approach reflects the expertise of the authors and it is quite enough for one paper.

More specifically, we will begin with a theory review, noting how multinational firms have been added to the traditional competitive, constant-returns, model used by international trade economists for decades. We begin with early analyses that viewed the activities of multinationals as essentially a part of the theory of portfolio capital flows. This theory generated clear testable predictions, generally to the effect that multinational firms will be headquartered in capital-abundant countries and establish subsidiaries in capital-poor countries.

The next step in the evolution of the theory occurred early in the development of the industrial-organization-approach to trade. This "new trade theory" incorporated elements of increasing returns to scale and imperfect competition into traditional general-equilibrium models. But soon there was a bifurcation of the sub-theory on multinationals into two branches. One could be called the "vertical" model in which firms geographically separate production by stages. 
This approach followed directly from the earlier work on direct investment as a branch of the theory of capital flows. The other could be referred to as the "horizontal" model in which a given firm produces roughly the same goods or services in multiple countries. These two alternatives have very different empirical implications, as we will note later. ${ }^{1}$

A third step in the development of the theory was to combine these two approaches into a richer framework that allows firms to chose among domestic, horizontal, and vertical strategies. Markusen $(1997,2001)$ has dubbed this the "knowledge-capital model", and tries to clarify the key unifying assumptions.

In the course of discussing the relevant models, we will note their testable implications. We will be particularly interested in their predictions regarding how the volume and pattern of affiliate production relate to country characteristics. These characteristics include markets sizes, differences in market sizes, differences in relative factor endowments, and trade and investment barriers. We will be interested further in testable implications relating to the relationship between affiliate activity and trade in goods.

Following the theoretical discussion, we turn to a review of empirical studies that address these questions. Empirical evidence suggests strong support for the horizontal approach, but little support for the vertical approach. The hybrid or "knowledge-capital" model gets good support, but in some cases the evidence does not allow it to be distinguished from the horizontal model.

\footnotetext{
${ }^{1}$ Unfortunately, these terms have been defined to mean somewhat different things by different authors. Furthermore, there is rarely a "pure" case of horizontal production in the sense that there is inevitably some vertical component to a firm. The services of firm-specific assets are supplied from parents to subsidiaries, even if the same final goods are produced in both parent and host countries. Further discussion is postponed until the next section.
} 


\section{Direct Investment as a Capital Flow: A Factor-Proportions Approach}

Early approaches to direct investment started with the basic workhorse model of international trade theory, the Heckscher-Ohlin model, or at least some sort of basic competitive factor-proportions model. There was no attempt to theoretically differentiate direct investment from portfolio investment. Factor-endowment differences between countries, combined with trade costs or specialization, meant that factor prices were not equalized internationally. Early papers, including MacDougall (1960) and Kemp (1962), often had a normative focus, addressing policy concerns about the appropriateness of restrictions to inward investment. Authors noted that a capital-scarce country could import capital up to the point where the return to capital was equalized internationally, and capture infra-marginal gains on the inward investment in ways that improved welfare.

A more realistic approach was taken by Caves (1971), who used the Jones (1971) specific-factors model instead of a Heckscher-Ohlin structure. Caves argued that direct investment is associated with firm-specific capital, and thus investment moved from an industry in the parent country to the same industry in the host country. The model was still a competitive, constant-returns approach in which firms are not really identified as distinct from industries, but Caves' paper was an important step in identifying something that differentiates direct investment from portfolio flows of homogeneous capital.

Although several papers had a normative focus as just suggested, these models have clear positive implications. Capital, whether of the homogeneous Heckscher-Ohlin variety or the sector-specific variety, tends to flow from where it is abundant to where it is scarce. In particular, there is no motive for direct investment between identical countries. 
3. Refinements of the Factor-Proportions Approach: the Vertical Model of the Multinational $\underline{\text { Firm }}$

The early 1980s saw the beginning of the industrial-organization approach to trade, which incorporated increasing returns to scale and imperfect competition into the general-equilibrium model of trade. In the latter, firms typically produced a single product in a single location. This is of course the pervasive assumption in the "strategic trade-policy" literature, which inevitably assumes single-plant, nationally-owned firms competing in world markets via exports.

An early model of multinationals was that of Helpman (1984), followed by Helpman (1985) and Helpman and Krugman (1985). We refer to these as "vertical" models, although some discussion of the terminology is needed. An alternative would be to use Brainard's (1993b) term and refer to these models as "factor-proportions explanations" for multinational activity. Helpman (1984) modeled a sector (X) as having two activities, a headquarters activity that produces blueprints, management, and the like, and a production activity. These two activities have different factor intensities, and they can be costlessly split apart geographically. The paper assumed zero trade costs, an assumption also made in Helpman (1985) and Helpman and Krugman (1985).

Helpman (1984) mentioned firm-level scale economies, which are vital to the theory of horizontal multinationals as we will see in the next section. But with the assumption of zero trade costs, this possibility plays no role. Within the factor-price-equalization (FPE) set, there is no advantage to multinationals and they do not arise. The focus of Helpman's paper was on points outside the FPE set, where firms have an incentive geographically to separate headquarters from plant. Specifically, multinationals are single-plant firms that geographically fragment the production process and arise only if countries differ sufficiently in their relative endowments of 
the two factors.

Helpman (1985) presented a significantly more complicated model and referred to multinationals as being both horizontally and vertically integrated. Here is where the terminology gets somewhat messy and it is our view that Helpman used the term "horizontal" in a non-standard way. In this model, enterprises are multi-product firms producing a range of differentiated final goods. Inside the FPE set, there is again no motive for multinational firms to exist. Outside this set, a firm may locate production of some varieties in one country and other varieties in another country. Each variety is sold in both countries, so intra-firm (cross-hauling) trade necessarily occurs along with multinational production. As in the case of earlier papers, multinational activity is therefore associated only with significant differences in relative endowments across countries.

Helpman (1985) thus used the term "horizontally integrated multinationals" to refer to firms producing a set of differentiated final goods, some at home and some abroad, with each variety being traded intra-firm. Many other authors, including some writing in the international business literature, use the term "horizontal" multinational to refer to firms that produce the same product or service in multiple countries and serve local markets by domestic production of that product rather than through trade. From this point of view, Helpman's definition does not fit very well into the horizontal approach, nor does it fit very well into the vertical approach as that term is often used. It does fit nicely into Brainard's terminology as a factor-proportions approach to the multinational and direct investment, in that differences in factor prices across countries are the motive for direct investment.

When we refer to the "vertical model" subsequently in this paper, we will have in mind 
Helpman (1984) and Helpman and Krugman (1985) as primary examples. Specifically, vertical firms will refer to single-plant firms that fragment the production process into stages based on factor intensities and locate activities according to international differences in factor prices.

Regardless of the confusing terminology, the set of papers referred to in this section have clear testable implications. They predict that multinational activity will arise between countries that differ significantly in relative endowments and will not arise between very similar countries. We emphasize that this is as much due to the assumptions about zero trade costs as it is to the assumptions about technology. However, given the constellation of assumptions in these papers, their predictions do not differ substantially from those of the older literature, which posited a technical equivalence between direct investment and portfolio capital movements.

\section{4. $\quad$ A Horizontal or "Proximity-Concentration" Approach}

Models that predict no role for multinational investment between similar countries are absolutely inconsistent with even the most casual glance at the data. But that is getting ahead of the story. An early model of an alternative approach to the multinational was the horizontal model of Markusen (1984). This model assumes the existence of firm-level scale economies as the driving force for direct investment. Two-plant firms have fixed costs that are less than double those of a single-plant firm, and therein lies the motive for multinational production. Multinationals are defined as firms that produce the same product in multiple plants, serving local markets by local production. Henceforth, this is what we will mean by a horizontal multinational, although such firms nevertheless do have some vertical element to them in that the services of firm-specific assets are produced in a headquarters location and supplied to a foreign 
plant. $^{2}$

Extensions of this model are found in Horstmann and Markusen $(1987,1992)$ and Brainard (1993a), who referred to this approach as the "proximity-concentration" hypothesis. General-equilibrium extensions that make the model more comparable to the Helpman-Krugman vertical model are found in Markusen and Venables (1998, 2000), the latter also relying on the world Edgeworth box as a tool of analysis.

While the Markusen and Venables papers allow a comparison to Helpman-Krugman, the two approaches nevertheless generate very different predictions. Suppose we rule out vertical firms that have a headquarters in one country and a plant in the other country. ${ }^{3}$ Perhaps there is an intrinsic connection between production and research so that one plant must be located together with the headquarters. Thus, firms are either "domestic" firms with a single plant and headquarters in one country or "horizontal" multinationals with a headquarters in one country and plants in both countries.

The horizontal model predicts that, given moderate to high trade costs and plant-level and well as firm-level scale economies, multinational activity will arise between similar countries. The intuition is best explained by considering what happens when two countries are asymmetric in either size or in relative endowments. Suppose first that the countries are of very different

\footnotetext{
${ }^{2}$ We should emphasize again that Helpman (1984) mentioned firm-level scale economies but, due to the reliance on the FPE set and the assumption of zero trade costs, two-plant horizontal firms could not arise in equilibrium and they were not discussed in the paper. There are really two alternative assumptions, either or which will rule out two-plant horizontal firms. First, zero trade costs can be assumed as in Helpman (and there may or may not be firm-level scale economies). Second, it can be assumed that there are no firm-level scale economies (and there may or may not be positive trade costs).

${ }^{3}$ Horizontal models including Markusen and Venables $(1998,2000)$ generally assume that fixed and variable costs have the same factor intensities, unlike the assumption used by Helpman. The former assumption largely, but not completely rules out incentives to vertically fragment a single-plant firm. See Markusen (2001), chapter 8 .
} 
sizes. Horizontal multinationals will be at disadvantage relative to domestic firms headquartered and producing in the large country. The multinational would have to install costly capacity in the small market, while the domestic firm would just incur trade costs on a relatively small amount of output exported to the small market. Suppose instead that the countries are of similar size but have very different relative endowments. Let skilled labor be the factor of production used intensively in the multinational sector in both fixed and in variable costs. Horizontal multinationals may now be at a disadvantage in that they have to incur a substantial portion of costs in a high-cost location. Domestic firms located in the skilled-labor-abundant country, on the other hand, incur all of their costs in the low-cost location.

\section{An Integrated Approach: the Knowledge-Capital Model}

Now allow firms to take on three different configurations. Single-plant firms with a headquarters and plant in the same location are referred to as domestic or type-d firms. Singleplant firms with a headquarters and plant in different countries are referred to as vertical or typev firms. Two-plant firms with a headquarters in one country and a plant in the other country are referred to as horizontal or type-h firms. Three crucial assumptions about technology constitute what Markusen $(1997,2001)$ refers to as the knowledge-capital (KK) model.

(A) Fragmentation: the location of knowledge-based assets may be fragmented from production. Any incremental cost of supplying services of the asset to a single foreign plant versus the cost to a single domestic plant is small.

(B) Skilled-labor intensity: knowledge-based assets are skilled-labor intensive relative to final production. 
(C) Jointness: the services of knowledge-based assets are (at least partially) joint ("public") inputs into multiple production facilities. The added cost of a second plant is small compared to the cost of establishing a firm with a local plant.

The first two properties, fragmentation and skilled-labor intensity motivate vertical (typev) multinationals that locate their single plant and headquarters in different countries depending on factor prices and market sizes. The third property, jointness, gives rise to horizontal (type-h) multinationals, which have plants producing the final good in multiple countries. Jointness is the key idea motivating the existence of firm-level scale economies.

It is important to note that properties (A) and (C) are not the same thing. A knowledgebased asset, such as a skilled engineer, may be easily transported to a foreign plant, but may be fully rival or non-joint in that his or her services cannot be supplied to two plants at the same time. Using alternative terminology, a firm may be able to geographically fragment production at low cost without having firm-level scale economies. Fragmentation is related to the concept of "technology transfer cost", or the ease of supplying services to a foreign plant. Fragmentation relates to supplying services to a foreign plant, regardless as to whether or not the firm has a domestic plant as well.

Jointness refers to the ability to use the engineer or other headquarters asset in multiple production locations without reducing the services provided in any single location. A blueprint is the classical example of a joint input. Jointness inherently refers to the costs of running two plants rather than one.

In the knowledge-capital model, both type-h and type-v multinationals can arise depending on country characteristics such as size, size differences, relative endowment 
differences, trade costs, and investment costs.

With this background, Figures 1-3 present simulation results from Markusen (2001, ch8, ch12). The underlying model has two countries $(\mathrm{i}, \mathrm{j})$, two goods $(\mathrm{Y}, \mathrm{X})$, and two factors (L -unskilled labor, S -- skilled labor). $\mathrm{Y}$ is produced with perfect competition and constant returns and is unskilled-labor intensive. $\mathrm{X}$ is a homogeneous good produced with increasing returns under Cournot competition. Markets are segmented. There are six possible firm types and there is free entry and exit into and out of firm types.

Type $h_{i}$ - $\quad$ horizontal multinationals which maintain plants in both countries, headquarters is located in country $i$.

Type $h_{j}$ - $\quad$ horizontal multinationals which maintain plants in both countries, headquarters is located in country $\mathrm{j}$.

Type $d_{i}-\quad$ national firms that maintain a single plant and headquarters in country $i$. Type $d_{i}$ firms may or may not export to country $j$.

Type $d_{j}-\quad$ national firms that maintain a single plant and headquarters in country $j$. Type $d_{j}$ firms may or may not export to country $i$.

Type $\mathrm{v}_{\mathrm{i}}$ - $\quad$ vertical multinationals that maintain a single plant in country $\mathrm{j}$, headquarters in country i. Type $v_{i}$ firms may or may not export to country $i$.

Type $v_{j}$ - vertical multinationals that maintain a single plant in country $i$, headquarters in country $j$. Type $v_{j}$ firms may or may not export to country $j$.

Factor-intensity assumptions are crucial to the results of the model. These are guided by what we believe are some empirically relevant assumptions. First, headquarters activities are more skilled-labor intensive than production plants (including both plant-specific fixed costs and marginal costs). This implies that an "integrated" type-d firm, with a headquarters and plant in the same location, is more skilled-labor intensive than a plant alone. Second, we assume that a plant alone (no headquarters) is more skilled-labor intensive than the composite Y sector. This is 
much less obvious, but some evidence suggests that this is probably true for developing countries: branch plants of foreign multinationals are more skilled-labor intensive than the economy as a whole. Assumptions on the skilled-labor intensity of activities are therefore:

$$
\frac{\underline{\text { Activities }}}{[\text { headquarters only }]>[\text { integrated } \mathrm{X}]>[\text { plant only }]>[\mathrm{Y}]}
$$

A complete specification of this model is found in Markusen (2001). A numerical version of the model is solved over various parameter values, with the solution giving the types and numbers of firms active in equilibrium. However, available data do not provide figures on both numbers and types of firms, but rather the values of foreign affiliate production and sales. The simulation model can focus on these variables, and output is what is shown in Figures 1-3. These diagrams are world Edgeworth boxes, with the world endowment of skilled labor on one axis and the world endowment of the other composite factor (called unskilled labor) on the other axis. Country $i$ is measured from the near or southwest (SW) corner, and country j's endowment from the far or northeast (NE) corner. The volume of affiliate production is measured on the vertical axis. This is defined as the value of the output of plants in country $\mathrm{j}$ of firms headquartered in country $\mathrm{i}$; that is, the output of type- $\mathrm{d}_{\mathrm{i}}$ and type- $\mathrm{h}_{\mathrm{i}}$ firms in country $\mathrm{j}$, and similarly for plants in country $\mathrm{i}$ of firms headquartered in country $\mathrm{j}$.

Figure 1 shows results for the knowledge-capital model, with trade costs $20 \%$ of marginal production costs (20\% is also used in Figures 2-3). Along the SW-NE diagonal where the countries differ in size but not in relative endowments, there is an inverted-U shaped pattern, indicating that affiliate production is highest when the countries are the same size. The multinationals active here are type-h, two-plant horizontal firms. At the center of the box, each 
firm has symmetric plants in both countries, so exactly half of all world output is affiliate output.

The highest values of affiliate output in Figure 1 occur when one country is both small and skilled-labor abundant. In this situation, most or even all of the firms are type-v firms headquartered in the small country, with a single plant in the large, skilled-labor-scarce country. The location of headquarters is chosen on the basis of factor prices, and the location of the plant is chosen both on the basis of factor prices and on the basis of market size. These motives reinforce one another for type-v firms when one country is small and skilled-labor abundant. Note that when all firms are type-v, then all world $\mathrm{X}$ output is, by definition, affiliate output. This explains the high affiliate production along the western and eastern edges of the Edgeworth box in Figure 1.

Figure 2 presents results for a restricted version of the same model, which we will call the horizontal (HOR) model. There are two changes from the model used to generate Figure 1. First, there is something inherent in the technology that makes fragmentation costs very high, such as the need for critical revision and feedback between the local plant and R\&D personnel and managers. In particular, assume that the total fixed costs of a type-v firm are the same as for a type-h firm. ${ }^{4}$ Second, the model is re-calibrated so that all X-sector activities (marginal costs, firm fixed costs, and plant fixed costs) use factors in the same proportion in Figure 2. Thus there is not a factor-price motive for fragmenting activities.

Results in Figure 2 show that affiliate activity is most important between countries that are similar in both size and in relative endowments. Earlier, we explained why differences in

\footnotetext{
${ }^{4}$ For example, suppose that firm-level fixed costs and the cost of a local plant are 10, but total fixed costs for a foreign plant are 6 regardless of whether or not there is a domestic plant. Then fixed costs are: type-d = 10, type-h $=16$, type- $v=16$. In such a situation, type-v firms will generally not arise, which is the result in Figure 2.
} 
size or in relative endowments imply advantages for domestic firms headquartered in the large and/or skilled-labor-abundant country. At the center of the box, all firms are symmetric type-h firms, and so exactly half of all world X output is affiliate output. When one country is a bit smaller and more skilled-labor abundant, most of the headquarters of the type-h firms are located in the smaller, skilled-labor-abundant country while more of the production is located in the other country. Thus more than half of world output is affiliate output, which explains the twin peaks in Figure 2. More generally, above the SW-NE diagonal most of the firms are headquartered in the skilled-labor-abundant country i. Thus, considering one-way activity (affiliates of country i firms producing in country $\mathrm{j}$ ), outward investment is still positively related to a country's skilled-labor abundance.

The empirical implication of the HOR model is thus straightforward. Affiliate production should be most important among countries that are similar in both size and in relative endowments. But considering one-way activity, a country's outward affiliate activity will be positively related to the country's skilled-labor abundance.

Figure 3 presents results from a model that makes only one change from the KK model of Figure 1. Figure 3 raises fixed costs for type-h firms until they are double the fixed costs for type-d firms so that there is are no firm-level scale economies arising from jointness. All other features of the model are the same as in Figure 1, including $20 \%$ trade costs. We will label the model of Figure 3 the vertical (VER) model. ${ }^{5}$

Figure 3 is similar to Figure 1 (and indeed identical at many points) when countries differ

\footnotetext{
${ }^{5}$ The pattern of affiliate production looks very similar to Figure 3 under the alternative assumption that there are firm-level scale economies, but zero trade costs. This alternative formulation is much closer to that of Helpman (1984) and Helpman and Krugman (1985), but generates essentially the same predictions as just noted.
} 
in relative endowments. But Figure 3 has no multinationals active when countries are similar in relative endowments, in spite of the high trade costs. Indeed, there are no type-h firms active anywhere in the Edgeworth box of Figure 3. In the central region of the box, type-d firms export at a price greater than marginal cost, and so have an advantage over type-h firms which would have twice the fixed costs, but only local sales in each market.

The difference between Figure 3 and Figure 2 is striking, and they clearly have different predictions as to how affiliate production should be related to country characteristics. Figure 2 , in which type-h firms arise but type-v firms are excluded by assumption, has multinationals arising between countries that are similar in size and in relative endowments. In Figure 3, in which type-v firms arise but no type-h firms exist, multinationals arise between countries that differ in relative endowments and are particularly important when one country is both small and skilled-labor abundant.

\section{Trade versus Affiliate Production in the Knowledge-Capital Model}

It seems clear that affiliate production and trade in good $\mathrm{X}$ should be substitutes in the horizontal approach to the multinational, although the theoretical relationship can become more complicated when there are both intermediate and final goods produced within the firm. It also seems reasonable to conjecture that affiliate production and trade in $\mathrm{X}$ should be complements in the vertical approach. Specifically, if there is a foreign assembly plant that exports back to the parent country, the activity generates both affiliate production and trade. Empirically, both trade and affiliate production have clearly been rising throughout the world in recent years, but this may be merely a correlation based on fairly aggregate data, rather than a demonstration of 
complementarity.

In this section, we will look at how the knowledge-capital model generates predictions about the relationship between affiliate production and trade in X. Our first task is to define exactly what we mean by complements or substitutes. In more general microeconomics, we do this in terms of comparative-static experiments, such as asking how the demand for $\mathrm{X}$ is affected by a change in the price of $\mathrm{Y}$. Here we will follow this methodology, and consider two experiments. First, we consider the effect of lower trade costs and the volume of affiliate production. Second, we consider the effects of liberalizing investment, beginning from a situation in which multinationals are banned, on trade in $\mathrm{X}$. We do this once again over the world Edgeworth box since, as we will see, the results depend very much on country size and relative-endowment differences.

Figure 4 shows the effects of reducing trade costs from $20 \%$ to $1 \%$ on the volume of affiliate production. First, we see that the volume of affiliate production falls in a central SW-NE region where the countries are similar in relative endowments and not too different in size. This corresponds to the elimination of type-h firms: with zero trade costs and plant-level scale economies firms will not build branch plants. Above and below this central SW-NE region in Figure 4 are regions in which the volume of affiliate production increases (gray shading). Consider the upper or more northwesterly of these two gray-shaded regions. With high trade costs, the region is generally type-h and type-d firms headquartered in the skilled-labor-abundant country (country i) or type-h firms only. Trade liberalization leads to the type-h firms being replaced by type-v firms headquartered in county i. We could think of this as "plant closures" in country $i$, with the lost output replaced with increased output in the county-j branch plants that is 
shipped back to country i. But the latter is counted as affiliate output while the lost output of the closed local plants is not. Thus the reorganization of X-sector output leads to an increase in total world affiliate output. Defining complements and substitutes as changes in affiliate production following trade liberalization, we can therefore say rather loosely that affiliate production and trade are substitutes for very similar countries and complements for countries differing in relative endowments.

Figures 5 and 6 reverse the experiment, asking what happens to the volume of $X$ trade when investment is liberalized, beginning with a situation in which multinationals (type-h and type-v firms) are banned. Figure 5 show the results with high trade costs (20\%) while Figure 6 shows the result with low trade costs $(1 \%)$. Consider the gray-shaded region on the "west" of Figure 5. When multinationals are banned, there is a tension in determining "comparative advantage" and the location of X production. Country $\mathrm{i}$ has an advantage in that it is skilledlabor abundant, but country $\mathrm{j}$ has an advantage in that it is large. In this simulation, the tension is resolved in favor of country $\mathrm{j}$, which exports $\mathrm{X}$ to country $\mathrm{i}$ (produced by local type-d firms). Investment liberalization switches some of these type-d firms to type-v firms headquartered in country $i$ with a single plant in country $j$. This regime shift frees up scarce skilled labor in country $\mathrm{j}$ for actual production, which increases along with exports of X. In the central region of Figure 5, the volume of $\mathrm{X}$ trade falls as type-h firms displace type-d firms.

In Figure 6 where investment is liberalized in the presence of low trade costs, we have four regions in which the volume of trade increases. We could call these regions southwest, northeast, north-central and south-central. In the southwest and northeast regions, the explanation for the increased trade volume is the same as in the previous paragraph: type-v firms 
enter in the small, skilled-labor-abundant country, freeing up skilled labor in the large country for production and export.

In the north-central region of Figure 6 the explanation is similar, but the cost savings are not sufficient to induce a regime shift with high trade costs (Figure 5). In the north-central region of Figure 6, domestic (type-d) firms headquartered in the skilled-labor-scarce country $\mathrm{j}$ are displaced with vertical (type-v) firms headquartered in the skilled-labor-abundant country i following liberalization. Again, this frees up skilled-labor for production in country $\mathrm{j}$, and exports increase. We should note that trade volume here refers to gross (two-way) trade in X. In general, the increased volume of $\mathrm{X}$ exports from country $\mathrm{j}$ in the north-central part of Figure 6 comes entirely at the expense of exports from $\mathrm{i}$ to $\mathrm{j}$, and thus that the net volume of trade in $\mathrm{X}$ falls.

It is not easy to make any precise statements from the results shown in Figures 4-6. In does appear that in some loose sense we can suggest that affiliate production and trade tend to be substitutes for similar countries. However, they tend to be complements for countries with widely differing relative factor endowments.

\section{Econometric Studies of General-Equilibrium Models of the Multinational Enterprise}

We reiterate that our intention in this paper is to focus on papers that have analyzed the determinants of plant location and firm type within general-equilibrium models. Thus, despite the considerable interest that such studies bear, we do not consider analyses that focus on alternative determinants arising from other approaches to FDI. This literature is enormous and could command several survey papers on its own. Useful reviews of some of that analysis are in 
Maskus (1998a) and Markusen (1995). For completeness, however, it is worth mentioning a few such papers of particular note.

Alternative approaches essentially may be categorized broadly into four areas, though these are not independent. First, we may think of FDI as motivated by changes in macroeconomic conditions. In this conception, foreign direct investment is a component of aggregate economic activity that responds to such variables as market size, growth, unemployment, exchange rates, stability, and risk. Prominent papers in this area include Wheeler and Mody (1992), Barrell and Pain (1996), Cushman (1985), Goldberg and Kolstad (1995) and Blonigen (1997). The Blonigen paper is particularly interesting for it establishes a linkage between exchange rate changes and the value of firm-specific assets that motivate the industrial-organization approach to multinational activity.

A second area is the role of policy in attracting or repelling FDI, particularly as regards taxes on corporate activity. Grubert and Mutti (1991), UNCTAD (1996), Maskus (1998b), and Blonigen and Davies (2000) provide evidence that FDI flows are sensitive to international variations in taxes and incentives. However, Brainard (1997) found that host-country corporate taxes do not seem to repel affiliate activity and Markusen (1995) argues that the jury is still out on that issue. We note further the review by Jaffe, et al (1995) that cannot detect any systematic relation between environmental regulation and FDI. However, as we discuss below, restraints on trade and investment do have important effects on multinational activity. In an important recent paper, Feinberg and Keane (2001) demonstrated that mutual tariff cuts by the United States and Canada induced a stronger export orientation on the part of Canadian affiliates of U.S. parent firms. Those affiliates also increased their sales in Canada. 
Third, several authors have detected empirical evidence that agglomeration effects importantly attract FDI flows at both the aggregate and sectoral levels. Wheeler and Mody (1992) and Woodward (1992) were early contributors to this literature, but the primary article is Head, Ries, and Swenson (1995), which found considerable agglomeration on the part of Japanese firms in their location decisions in the United States. If firms have preferences to locate near existing activity or near prior investments abroad by companies from their own countries or industries, the nature of dynamic competition depends on both flows of FDI and policies to influence them.

Fourth, some studies consider how firms invest abroad in order to exploit internalization advantages arising from proprietary knowledge or brand names. Such knowledge may be transferred abroad into productive use through FDI or licensing. It is evident from numerous studies that U.S.-based multinationals are disproportionately high investors in R\&D, both at home and in or for their foreign affiliates (Markusen, 1995). This result comes through powerfully in Brainard (1997), who also found that brand recognition, as proxied by advertising intensity of U.S. multinationals, is a strong determinant of foreign affiliate sales. Additional studies have shown that multinational enterprises condition their choices between FDI and licensing on the strength of local patent rights in various markets (Ferrantino, 1993; Maskus, 1998; Smith, 2001).

Finally, we note that there is an equally interesting literature about the effects that multinational activity may have on host and source countries. These papers consider such impacts as aggregate, sectoral, and factoral wage changes, productivity spillovers, and contributions to international trade. These questions are well beyond our scope. 


\section{1. $\quad$ FDI in Factor Endowment Models}

We began our theoretical review by explaining that the traditional approach considered FDI to be a portfolio flow in response to relative international capital scarcities. Given the strong empirical interest in the factor content of trade (e.g., Davis and Weinstein, 1998; Trefler, 1995) it is remarkable that this proposition has attracted so little econometric study. In some degree, papers that place relative factor costs into FDI equations implicitly are looking for correlations between factor prices in segmented markets and investment flows. For example, Wheeler and Mody (1992) incorporate wage costs while Feinberg and Keane (2001) employ both wages and capital costs. However, the authors tend to think of absolute labor and capital costs (or relative measures between host and source) as repelling factors to firms rather than reflections of differential factor abundance.

To our knowledge, the idea that FDI flows are a response to varying factor endowments in an HO model with production specialization has not been formally tested in a well-specified general-equilibrium model. This is all the more remarkable given the importance of the issue in the globalization debate. Moreover, it is not difficult to see how one could go about this task, at least in principle, by modifying basic trade equations to reflect "effective scarcities" of factors in comparison to a situation with integrated factor markets. An interesting start in this regard is Ekholm (1998a) who placed implicit measures of headquarters services into a calculation of the factor content of trade. Perhaps the relative absence of such work simply suggests that economists do not believe that FDI exists for the purpose of equilibrating capital markets, an observation that is consistent with reports that FDI flows are more stable than portfolio flows in the presence of financial crises. Indeed, the existence of multinational firms is awkward for the 
perfectly competitive assumptions of the HO model. Nonetheless, we think that more work could usefully be done in this framework. ${ }^{6}$

An important paper that should be mentioned in this context is Eaton and Tamura (1994). The authors placed measures of relative factor endowments into gravity equations explaining U.S. and Japanese exports, imports, and inward and outward FDI flows with approximately 100 countries over 1985-1990. Their essential interest was to discover whether the same features that explain international trade in a gravity framework are determinants of investment. In this context, they looked for complementarity between trade and FDI, an issue to which we turn next, rather than substitution as would be expected in an HO approach. Despite that predilection, their results suggested that Japanese firms engage in considerable FDI with countries that have low population densities (that is, they are scarce in labor relative to land), which suggests an attempt to compensate for land scarcity at home. In contrast, U.S. investment flows are disproportionately high with countries that share high endowments of human capital. Overall, they found high correlations among countries in attracting both trade and FDI, suggesting that the balance of evidence favors complementarity. Unfortunately, interpretations of such correlations are clouded by the possibility that both trade and FDI may be increasing as a result of some third factor.

Lipsey (1999) provides interesting descriptive evidence on whether U.S. and Japanese multinationals follow comparative advantage in their investments in developing countries of East Asia. He found that Japanese firms invested heavily in sectors of host-country comparative advantage, such as textiles and apparel and other manufacturing, though these affiliates initially

\footnotetext{
${ }^{6}$ Maskus and Webster (1995) provide one simplified attempt.
} 
were not heavily oriented toward export production. In contrast, U.S. firms made early investments in electronics and computer-related machinery, which were sectors of American comparative advantage at the time, but focused that production on exports. Over time the Japanese affiliate production mix and exports converged toward the U.S. pattern and became concentrated in electric machinery and transport equipment, both for domestic sales and exports. This evidence is intriguing, for it suggests that comparative advantage of both source and host countries may be involved in investment decisions. Again, more formal estimation in a structured framework would be beneficial.

\section{2. $\quad$ Are Trade and Investment Complements or Substitutes?}

As we discussed earlier, a fundamental question in general-equilibrium theory of the multinational firm is whether FDI substitutes for trade in goods or whether investment and trade move together as complements. Econometric models of substitution possibilities can, therefore, provide indirect evidence on the nature of multinational activity. In terms of the theories reviewed, substitution is the expected relationship under horizontal investment as firms economize on transport costs and trade barriers in servicing markets of similar size and endowments. The relationship would be complementary in vertical investments, particularly if vertical fragmentation results in the production of both intermediates and final goods within the firm.

There is again a large literature on the substitution versus complementarity effects of FDI and we consider only a few studies in detail. Early contributions were Swedenborg (1979) and Lipsey and Weiss $(1981,1984)$, which found positive correlations between a country's exports 
and foreign affiliate sales, using aggregate, industry-level, and firm-level data. See also Blomstrom, et al (1988) for related evidence using firm-level data from the United States and Sweden.

Lipsey (1991) found in a descriptive review of the sales, imports, and exports of foreignowned manufacturing affiliates in the United States that firms in different industries may behave differently. He found higher export shares of foreign-owned affiliates than for U.S. parent firms in metals and chemicals, suggesting that foreign multinationals brought to the United States both technological advantages and access to their source markets. In this regard, FDI and exports are complements for the host country in the sense that investment both reduces costs and raises export demand. However, the situation was different for non-electrical machinery and transport equipment, in which foreign-owned affiliates produced primarily for the U.S. market, thereby substituting for imports from foreign parents.

In an important paper, Blomstrom, et al (1997) provided a statistical analysis of the substitution effects FDI may have on labor demand and employment in source countries. Using confidential firm-level data from U.S. parents, they considered the effect of affiliate net sales (controlling for the level of parent sales) on parent employment. Interestingly, when they distinguished between foreign sales in developed countries and foreign sales in developing countries, they discovered a significantly negative impact of the latter on parent employment and no effect of the former. Thus, U.S. parent firms do tend to substitute foreign production for home employment when they invest in developing nations and, according to their calculations, an increase in foreign sales by one million dollars reduces U.S. employment by 12-18 workers. This effect does not hold in developed host nations, however. 
Corresponding analysis of Swedish firms by the authors discovered a significant difference. ${ }^{7}$ They found that the coefficient on host sales was positive and significant throughout the period 1970-1994, suggesting that foreign affiliate production raises the demand for Swedish labor. This result held also for sales in developing countries. Interestingly, the sales coefficient declined continuously over the period, which they attribute informally to a declining need for parent employment for purposes of monitoring and supervision of foreign affiliates. This result deserves further analysis. We note also that a number of econometric difficulties could be raised about the paper. There are likely to be substantial questions of endogeneity in a regression of parent employment on foreign sales, while it would be interesting to sort out the directions of causality. Moreover, their regression equations are remarkably parsimonious and the coefficients may suffer from omitted variable bias, rendering their comparative-static policy experiments questionable. For example, the equations are missing measures of trade costs, investment barriers, and foreign factor intensities. We note that such problems are common in this literature, contributing to the lack of clarity and consistency in results.

An improvement is the analysis by Brainard and Riker (1997) who took the question of substitution seriously by estimating a translog cost function for U.S.-owned foreign affiliates in approximately 90 countries over $1983-1992 .{ }^{8}$ For this purpose they used confidential firm-level data and assume strongly that firms share a single production function across host locations. This approach requires laborers in each country to be in perfectly elastic supply, so that wages are exogenous to the firm, though it permits differentiation of workers across sites. Thus, the

\footnotetext{
${ }^{7}$ See also Lipsey, et al (2000), which demonstrated that foreign affiliate production of Japanese-owned firms is positively correlated with parent global exports and parent employment.

${ }^{8}$ See also Slaughter (2000).
} 
authors computed labor-labor substitution across foreign (and parent) plants, establishing an explicit labor-market linkage. This could not be done in a completely flexible manner because of data limitations, so they assumed a short-run cost function with fixed capital. They further experimented by aggregating sites by geographical proximity to the United States (Western versus Eastern hemispheres) and by level of development. The last assumption reflected the notion that developed and developing countries could differ in relative skill supplies and therefore offer different substitution possibilities. Given the nature of the data their translog specification was limited to cost shares, wages, firm fixed effects, and year fixed effects.

Their results suggested that labor substitution is high among locations at similar levels of economic development, especially in low-value added sectors in developing nations, though there is not much difference across locations. There is small net substitution with U.S. parent employment. However, activities by affiliates at locations with different skill levels (proxied by level of development, or per-capita income differences) reveal complementarity. The authors interpreted these findings to mean that substitution is highest among workers at alternative lowwage locations but that production by affiliates in countries with differing skill levels displays a vertical and complementary division of labor. Thus, the most intensive competition resides between laborers in developing countries, while foreign investment only marginally reduces U.S. parent employment.

In our view, these results are intriguing but not decisive. It is important to analyze the substitution question in a coherent framework, as the authors have done, which helps interpret the findings consistently. Nonetheless, the authors were constrained to make a number of simplifying assumptions and their findings say little about the extent of long-run substitution of 
labor across borders. Moreover, there was no discussion in the paper of how well the results satisfied required regularity conditions. More work along these lines would be beneficial.

Another interesting recent paper is Head and Ries (2001), who developed a simple theory in which FDI could result in substitution with exports in horizontal models but in complementarity due to demand effects and vertical integration raising intra-firm trade. They employed count data for 933 Japanese firms that engaged in FDI over 1966-1990. Their sample provided a natural experiment within which to see whether complementarity in FDI and parentcountry exports stems from demand effects or vertical integration, because many of the firms are horizontal Keiretsu in the automobile and electronics sectors. They were also able to control simply for heterogeneity in firm productivity. They found that firms with higher manufacturing investments overseas tend to have higher exports, controlling for firm size, capital intensity, productivity, number of distribution investments, and fixed effects for firms and years. Thus, overall, Japanese FDI results in net complementarity. The authors calculated that a $10 \%$ rise in FDI abroad in distribution and manufacturing would increase Japanese exports by $1.5 \%$ and $1.2 \%$, respectively.

Furthermore, a measure of vertical integration of Japanese firms had a positive interaction in the exports equation with overseas manufacturing investments, suggesting such integration expands trade within integrated firms. At the same time, the non-vertically integrated Keiretsu firms showed substitution between foreign production and exports. Thus, in inherently horizontal leading firms, foreign output tends to displace parent exports. Overall, therefore, their results strongly suggest that horizontal investment tends to substitute for home production and exports, while vertical investment provides a channel for expanding home exports through intra- 
firm trade in intermediates.

This line of inquiry was extended by Blonigen (2001). He noted that a problem with prior studies was that aggregate, industry, or even firm-level data (for multi-product firms) could not sort out vertical linkages that expand demand for intermediates from competitive substitution effects. However, product-level data on trade and foreign production provide more scope for such discrimination, because products may be classified as differentiated consumer goods, which should be sensitive to export replacement in horizontal competition, and intermediates, which should experience rising exports as firms invest abroad in goods that use those intermediates. However, even intermediate inputs could suffer net substitution over time if final-goods producers shift intermediate production abroad as well. Blonigen explored these possibilities in two data sets, one involving Japanese exports of specific automobile parts to the United States and one involving detailed categories of final consumer goods exported to the same market. All products were chosen so that there was Japanese-owned production in the United States as well. The author hypothesized that there would be net complementarity between U.S. production of Japanese-owned automobile factories and Japanese exports of automobile parts, but net substitution between those exports and U.S. affiliate production of parts. There should also be net substitution in final consumer goods.

Blonigen developed a simple model of import demand, assuming perfect substitution between Japanese products and U.S.-produced versions. Unfortunately, he was unable to model firm supply decisions, so questions remain about the meaning of the reduced-form coefficients. The author employed instruments for U.S. employment (a proxy for sales) in the exports equations, expecting the coefficients to be negative if there were a relationship of substitution. 
In Zellner iterative SUR equations for 10 automobile parts categories with the dependent variable being exports to the United States of Japanese auto parts, Blonigen found negative but small coefficients for U.S. automobile parts production in Japanese-owned affiliates but positive and large coefficients for Japanese-owned automobile production. These results strongly suggest that a primary source of complementarity between FDI and trade is induced increases in demand for intermediate inputs. Regarding consumer goods, nine of 11 categories registered negative relationships, seven of these being statistically significant, between U.S.-based affiliate production and Japanese exports. Thus, substitution dominates for those products. Interestingly, substitution impacts appear to be large one-time changes rather than gradual movements over time.

Our reading of this literature suggests that it has moved from a frustrating degree of ambiguity in results and clarity in interpretation, stemming largely from weak statistical and econometric methods (albeit conditioned on limited data), to a much sharper picture in which complementarity stems primarily from increases in demands for intermediates in vertical relationships, and substitution emerges from trade displacement among final goods. We note that the complementarity story arises from studies of how foreign establishment of final-goods production facility rebounds into higher demand for intermediate goods. More formal studies of how these relationships emerge within vertically integrated firms would be useful, in order to assess whether these demand factors are two-way between affiliates and parents, as theory would suggest. Finer data definitions and close relationships to underlying theoretical models could improve this understanding even further. However, to place the basic inference into the context of our theoretical discussion, note that it suggests that models of vertical FDI in a single good 
(that is, with headquarters producing invisible services and the foreign plant producing the commodity according to factor costs) are not well supported by studies of substitution. More complicated models with intermediate production are supported, though they play little role in our earlier discussion. Substitution effects in horizontal models among similar products seem to dominate. 9

\subsection{Studies of the New General Equilibrium Models}

We turn, finally, to econometric studies of general-equilibrium models of multinational firms as described in prior sections of the paper. Our focus will be on three questions. First, what are the fundamental national characteristics and industry characteristics that give rise to multinational activity? Second, are the data capable of discriminating between various theories in terms of their statistical relevance? Third, what are the determinants of intra-industry affiliate activity in relation to intra-industry trade?

An important study is Brainard (1997), who distinguished between the "proximityconcentration hypothesis" and the "factor-proportions hypothesis" regarding multinational firms. In the former, firms face a tradeoff between wishing to be near customers and suppliers and sacrificing scale economies from single-plant production. To the extent that plant-level increasing returns are small relative to firm-level increasing returns, horizontal FDI would be prominent, particularly among countries with similar per-capita incomes and high trade barriers. Equilibrium could involve two-way horizontal multinationals with no exports, pure national

\footnotetext{
${ }^{9}$ See also Egger (1999?) and Denekamp and Ferrantino (1990) for evidence supporting this characterization.
} 
firms with no affiliate sales, or mixed solutions. This model is a variant of what we have termed the horizontal model.

The model Brainard took to the data captures these influences well. She noted the problems involved in endogeneity between affiliate sales and exports, so she focused on explaining shares of exports or affiliate sales in servicing particular markets. Thus, bilateral export shares (that is, parent-country exports divided by the sum of parent-country exports and affiliate sales) were modeled as linear in freight costs, bilateral tariffs, absolute differences in per-capita income (which she took to be a proxy for differences in factor endowments), corporate tax rates in the host, trade and investment costs in the host, and measures of plant scale economies and firm scale economies. She also worked with sales shares and, for inward data, import and sales shares. These models were applied to a cross-section in 1989 of 27 countries and 63 sectors with bilateral trade and affiliate sales with the United States. Because not all cases involved both types of trade she employed both OLS and a two-stage Tobit procedure, including country and industry random and fixed effects.

The results provided strong support for the proximity-concentration hypothesis. In particular, differences in per-capita income raise the export share, suggesting that income similarities are stronger determinants of affiliate sales than exports. Trade restraints, measured by a suggestive index from the World Competitiveness Report, significantly increased the share of affiliate sales compared to exports, while an index of investment costs (from the same sources) reduced that ratio. Most significantly, sectors with high plant scale economies saw high export shares while sectors with high firm scale economies saw low export shares. These basic results were confirmed by regressions on levels in addition to inward shares in the United States. 
Brainard interprets her findings as supportive of the horizontal model of FDI but contradictory to the factor-proportions hypothesis, which is consistent with her earlier empirical paper (Brainard, 1993b), which we review below. This is an important finding but she did not attempt a formal statistical discrimination between the two models.

An interesting attempt to implement the "convergence hypothesis" implicit in the horizontal model is Barrios, et al (2000). This hypothesis is that multinational activity should replace national firms and exports as countries get closer in relative size, relative endowments, and relative production costs. Employing a panel of bilateral affiliate employment levels for OECD countries over 1985-1996, they took as a dependent variable the MNE share of affiliate employment in total employment of host and source countries. Independent variables included the sum of parent and host GDP, absolute differences in GDP, absolute differences in skill endowments and capital endowments, the sum of R\&D in both countries (an attempt to capture ownership advantages of the firm, or firm-level fixed costs), bilateral distance, and a commonlanguage dummy. There are difficult econometric problems in their study, as they used a highly unbalanced panel and applied OLS without country fixed effects. We note also that their interpretation of the distance variable as capturing investment transactions costs is problematic given their failure to include a control for investment barriers. Given those caveats, their findings on the GDP variables and R\&D support the horizontal FDI model. However, the endowment variables provide ambiguous results, with differences in capital endowments positively affecting the affiliate employment share.

Carr, et al (2001) adopt a broader approach in estimating the knowledge-capital model. Its innovation lies primarily in incorporating non-linear terms into the econometric explanation 
of affiliate sales in order to capture some complexities in the simulation model (see Figure 1 above). Specifically, their basic estimation equation is:

$$
\begin{gathered}
\text { RSALES }=\mathrm{B}_{0}+\mathrm{B}_{1} \text { SUMGDP }+\mathrm{B}_{2} \text { GDPDIFSQ }+\mathrm{B}_{3} \text { SKDIFF }+ \\
\mathrm{B}_{4}(\text { GDPDIFF } * \text { SKDIFF })+\mathrm{B}_{5} \mathrm{INVCJ}+\mathrm{B}_{6} \text { TCJ }+\mathrm{B}_{7}(\text { TCJ } * \text { SKDIFSQ })+\mathrm{B}_{8} \text { TCI }+\mathrm{B}_{9} \text { DIST }+\mathrm{u}
\end{gathered}
$$

This specification relates the real volume of affiliate sales of either U.S.-owned manufacturing affiliates abroad or foreign-owned manufacturing affiliates in the United States to fundamental country characteristics. SUMGDP measures total bilateral market size and should positively affect sales. GDPDIFSQ is the square of the difference in country size, which should bear an inverted U-shape in relation to sales as relative sizes change, thereby predicting a negative coefficient. SKDIFF is the difference in relative skill endowments between host and source, with a positive anticipated coefficient reflecting the location of headquarters in skill-abundant nations and production in skill-scarce nations. The interaction between GDP sizes and skill differences should have a negative sign for the KK model strongly favors affiliate sales when the parent country is both small and skill-abundant. Variables capturing investment-cost barriers (INVCJ) and trade costs (TCJ) in the host country should have negative and positive signs, respectively, with the latter expectation based on the horizontal model. The interaction term between trade costs and squared differences in skill endowments captures the idea that trade costs may encourage horizontal investment but not vertical investment, while horizontal investment increases as endowments become more similar, suggesting a negative coefficient. Finally, trade costs (TCI) in the parent country should limit incentives for vertical FDI. They also included geographical distance (DIST) and argued that, while its sign would be ambiguous in theory, it would be negative to the extent that distance captures transactions costs in addition to those 
inherent in ICJ.

The authors estimated this model for a panel of 36 bilateral FDI partners with the United States over the period 1986-1994, incorporating fixed effects for recipient countries. Both weighted least squares (to correct for heteroskedasticity in levels) and Tobit procedures (to account for zero observations in sales) were employed. Like Brainard and Riker (1997), they developed measures of trade costs and investment costs from the surveys published in the World Competitiveness Report. Such measures are certainly problematic given their subjective nature, however they may be defended as reasonable reflections of actual perceptions on the part of multinational enterprise managers. The authors did not consider any potential endogeneity in the survey indexes.

The results were remarkably supportive of the knowledge-capital model. Consider the Tobit results from their Table $4(n=628$, coefficients in bold are significant at the $95 \%$ level or higher):

$$
\begin{aligned}
& \text { RSALES = -53341 + 16.6(SUMGDP }) \text { - } \mathbf{0 . 0 0 0 9}(\text { GDPDIFSQ })+\mathbf{2 9 3 6 6}(\text { SKDIFF })- \\
& \text { 7.7(GDPDIFF*SKDIFF })-41.3(\text { INVCJ })+\mathbf{1 4 4}(\text { TCJ })-2273(\text { TCJ*SKDIFSQ }) \text {-112.6(TCI }) \\
& \text { - } \mathbf{0 . 8}(\text { DIST })
\end{aligned}
$$

All signs are as expected and only two coefficients fail to achieve significance. This result survived a number of specifications for robustness.

An important feature of these results is that they may be used to perform comparativestatic experiments from changes in exogenous variables, accounting for non-linearities. These non-linear terms imply that the results are not necessarily the same for all country pairs (or, more precisely, in all regions of the Edgeworth Box), leading to a rich menu of potential conclusions. 
We simply repeat their basic propositions here. First, regardless of the country pair, an increase in host-country trade costs generates a rise in affiliate production, strongly suggesting that substitution effects dominate in the data. Second, a balanced rise in host-country and parentcountry trade costs tends to increase affiliate production when the non-U.S. partner is a developed country but to reduce affiliate production when it is a developing country. In the former case, trade and FDI are substitutes but in the latter case they are complements, consistent with horizontal and vertical investment, respectively. Third, a convergence in size between bilateral country pairs, holding total GDP constant, increases affiliate production in both directions. Fourth, an increase in the partner country's skilled-labor abundance increases both U.S.-owned affiliate sales and foreign-owned affiliate sales in the United States, supporting the notion that endowment convergence favors horizontal investment. Finally, a joint increase in both host and source GDP levels raises affiliate production relative to GDP because affiliate activity is income-elastic. This result is consistent with the rising ratio of foreign affiliate production to GDP seen in many parts of the world.

A natural extension of this approach is to ask whether national characteristics have different impacts on local production and exports (Markusen and Maskus, 2001a). Using the same data set as in Carr, et al, they regressed local affiliate sales, affiliate exports, and the ratio of affiliate exports to local sales on the same variables (excluding the interaction between host trade costs and squared skill differences). They found that joint market size has a larger positive impact on local sales than exports and therefore an increase in combined GDP significantly reduces the ratio of affiliate exports to affiliate sales. Raising host-country GDP alone has the same effect. In contrast, differences in parent versus host-country skill endowments have a 
larger effect on exports and increasing that difference substantially raises the ratio of exports to sales. Finally, the impacts of host-country investment costs and trade costs are considerably larger on affiliate sales than on exports. Investment costs have negative and significant coefficients in both equations. Trade costs have positive coefficients but only the sales impact is significant, which is intuitively sensible. Thus, the authors concluded that production for local sale is strongly attracted by trade protection while production for exports would be less interested in such protective locations. Further computations demonstrated that the elasticity of local sales with respect to an increase in host-country income is 1.6 , which exceeds the export elasticity of 1.1. However, the negative elasticity of exports with respect to an increase in host-country skill abundance (a movement toward the U.S. level) was larger in magnitude than that for affiliate sales. Thus, production for export sales is relatively more attracted to less skilled-labor abundant nations and production for affiliate sales is relatively more attracted by growth in market size.

From the theoretical analysis described in the first part of the current paper it is possible to specify the horizontal (HOR) and vertical (VER) models as nested versions of the knowledgecapital (KK) model. Accordingly, in a subsequent paper Markusen and Maskus (2001b) performed a statistical test to see which specification best fits their data set. For this purpose they defined two dummy variables, with D1 (= -1 or 0$)$ selecting cases where the host country is skill abundant relative to the source and the other ( $\mathrm{D} 2=1$ or 0 ) selecting the opposite cases. Taking KK to be the unrestricted model, affiliate sales volume should depend on the sum of GDP (SUMGDP), the squared difference in GDP (GDPDIFSQ), the second dummy interacted with the product of skill difference and GDP difference (D2*SKDIFF*GDPDIFF), the second dummy interacted with the product of skill difference and the sum of GDP (D2*SKDIFF*GDPDIFF), 
and the first dummy interacted with the same product (D1*SKDIFF*GDPDIFF). As suggested by Figure 2 above, HOR should not depend on D2*(SKDIFF)*(GDPDIFF) and thus that variable was not included in its regressions. As suggested by Figure 3 above, VER should not depend on SUMGDP and GDPDIFSQ and those coefficients were constrained to zero. Note from earlier work that these two variables have strong influences on affiliate activity, so this representation of VER was destined to be rejected. All three models permitted the inclusion of distance, hostcountry investment costs, and host-country and parent-country trade costs.

In the regressions, the interaction terms distinguishing KK from HOR were not significant in the former equations. Thus, the statistical tests could not discriminate between KK and HOR; essentially they are the same model. However, VER was rejected decisively at the 99\% level of confidence. Thus, the data sample employed in this paper rejected VER in favor of the HOR specification. One weakness of the approach was that the fit of these models depends, in principle, on the location of data points within the Edgeworth Box. Thus, one could argue that the data failed to include enough observations with significantly different factor endowments to support the VER model. We doubt this interpretation, however, both because 15 of the 26 countries in the sample were developing countries and because of the decisive nature of the rejection. 


\section{4. $\quad$ Intra-industry Affiliate Sales}

A new empirical literature, based on these general-equilibrium considerations, is emerging on the determinants of intra-industry affiliate production. It is evident that in models supporting the existence of horizontal multinationals in both markets, intra-industry affiliate sales (IIAS) should be a variable of considerable interest.

Greenaway, et al (1998) developed a series of measures that may be used to account for IIAS and intra-industry FDI. A readily interpreted index was offered by Ekholm (1997) in a paper that was among the first to attempt an explanation of IIAS. Her index is:

$$
\mathrm{IA}_{\mathrm{jk}}=1-\Sigma_{\mathrm{i}} \mid \mathrm{A}_{\mathrm{ijk}}-\mathrm{A}_{\mathrm{ikj}} / \Sigma_{\mathrm{i}}\left(\mathrm{A}_{\mathrm{ijk}}+\mathrm{A}_{\mathrm{ikj}}\right),
$$

where $\mathrm{i}=$ sector and $\mathrm{j}, \mathrm{k}$ indicate host and partner countries. This index clearly was inspired by the Grubel-Lloyd index of intra-industry trade and runs from zero to one. Because of data constraints she used intra-industry affiliate employment to construct the index. Her interest was in seeing how well the Helpman-Krugman (1985) model of FDI in differentiated products fits data on bilateral affiliate activity of U.S. and Swedish firms.

Employing a sample of 2-digit and 3-digit ISIC industries in 1990 for OECD partners, she regressed the log of this index on several national characteristics. First was the log of GDP in both host and parent, expecting positive signs. Second was the absolute difference in log GDP levels, expecting a negative sign because such activity should diminish with the degree of dissimilarity in size. Third were measures of differences in physical capital and human capital endowments. Dissimilarity in endowments should also diminish intra-industry activity, though she hypothesized that there would be a stronger effect from human capital differences. Controls were included for industry size and R\&D intensity. Using logit estimation because of the limited 
range of IA, Ekholm achieved results consistent with her hypotheses. Country size differences negatively affect intra-industry affiliate employment, as do differences in physical and, especially, human capital. R\&D intensity positively affects intra-industry activity, consistent with the internalization evidence we reviewed earlier.

An earlier investigation was Brainard (1993b), who specified Helpman-Krugman (1985) as the "factor proportions" hypothesis in which two-way FDI emerges in differentiated products. She calculated intra-industry sales (IIS) indexes to correspond with intra-industry trade (IIT) indexes for 27 bilateral U.S. partners in the 1989 BEA Benchmark Survey, with 64 industries matched between bilateral exports and affiliate sales categories. IIS ranged from 0 for Argentina and Brazil to 0.4 for the UK, while IIT ranged from 0.08 for Venezuela to 0.66 for Mexico. These indexes were highly correlated. She first adopted Helpman's (1987) regression model, with the log of two-way gross affiliate sales and trade flows related to the log of GDP sum, the $\log$ of two-country GDP dispersion, freight factors, and industry effects. GDP was insignificant in the sales equation but highly significant in the trade equation, while GDP dispersion was strongly positive in both. Going on to an explanation of IIS and IIT, she found that IIS was weakly related to endowment differences, strongly affected by GDP dispersion, and unaffected by freight costs. IIT was also weakly influenced by endowments but was strongly negative in transport costs. These results were consistent with a monopolistic competition model in which trade and intra-industry affiliate activities are not much affected by factor proportions. Thus, she concluded that the data support what she elsewhere termed the proximity-concentration hypothesis.

A final paper worth mentioning is the most recent work by Markusen and Maskus 
(2001c). They ran simulations that provided predictions about how IIS and IIT (using GrubelLloyd definitions) would be affected by national characteristics. In their regressions, IIS fits the theory quite well, for the index gets larger as two countries become more similar in size and relative endowments. IIT regressions also support the theory, though weakly. Considering the ratio of IIS to IIT, their findings suggested that "balanced" affiliate activity is more strongly encouraged by higher incomes and country similarity than is intra-industry trade.

\section{8. $\quad$ Concluding Remarks}

In this review, we have taken a somewhat narrow approach to a broad literature on multinational firms and direct investment. But circumscribing our efforts to recent theoretical and empirical analyses that adopt a general-equilibrium trade-theoretic view of the multinational generates quite enough for one paper.

Alternative theoretical approaches to the multinational are shown to generate different predictions as to how affiliate activity should be related to country, trade-cost, and investmentcost variables. These alternatives similarly suggest different relationships between affiliate production and trade. Overall, we believe that the empirical evidence gives strong support to the "horizontal" approach to the multinational and little support to the "vertical" approach. It is similarities between countries rather than differences that generates the most multinational activity. The integrated "knowledge-capital" approach gets good support, but in some cases cannot be clearly distinguished from the horizontal model. On the question of whether or not trade and affiliate production are complements or substitutes, evidence is slowly emerging that affiliate production complements increased trade in intermediates but in general substitutes for 
trade in final goods. The latter result is another finding that fits well with the predictions of the horizontal model. 


\section{REFERENCES}

Barrell, Ray and Nigel Pain (1996), "An Econometric Analysis of U.S. Foreign Direct Investment," Review of Economics and Statistics 78, 200-207.

Barrios, Salvador, Holger Gorg, and Eric Strobl (2000), "Multinational Enterprises and New Trade Theory: Evidence for the Convergence Hypothesis," Centre for Research on Globalisation and Labour Markets, research paper 2000/19.

Blomstrom, Magnus, Gunnar Fors, and Robert E. Lipsey (1997), "Foreign Direct Investment and Employment: Home Country Experience in the United States and Sweden", Economic Journal 107, 1787-1797.

Blomstrom, Magnus, Robert E. Lipsey, and K. Kulchycky (1988), "U.S. and Swedish Direct Investment and Exports", in Robert E. Baldwin, ed., Trade Policy Issues and Empirical Analysis, Chicago: University of Chicago Press, 259-297.

Blonigen, Bruce A. (1997), "Firm-Specific Assets and the Link Between Exchange Rates and Foreign Direct Investment", American Economic Review 87, 447-465.

Blonigen, Bruce A. (2001), "In Search of Substitution between Foreign Production and Exports", Journal of International Economics 53, 81-104.

Blonigen, Bruce A. and Ronald B. Davies (2000), "The Effect of Bilateral Tax Treaties on US FDI Activity", University of Oregon working paper.

Brainard, S. Lael (1993a), "A Simple Theory of Multinational Corporations and Trade with a Trade-off between Proximity and Concentration", NBER Working Paper No. 4269.

Brainard, S. Lael (1993b), "An Empirical Assessment of the Factor Proportions Explanation of Multinationals Sales", NBER Working Paper No. 4580.

Brainard, S. Lael (1997), "An Empirical Assessment of the Proximity-Concentration Tradeoff between Multinational Sales and Trade", American Economic Review 87, 520-544.

Brainard, S. Lael and David A. Riker (1997), "Are U.S. Multinationals Exporting U.S. Jobs?" NBER working paper 5958.

Braunerhjelm, Pontus and Karolina Ekholm (editors) (1998), The Geography of Multinational Firms. Boston: Kluwer Academic Publishers. 
Carr, David L., James R. Markusen and Keith E. Maskus (2001), "Estimating the KnowledgeCapital Model of the Multinational Enterprise", American Economic Review, forthcoming.

Caves, Richard E. (1971), "International Corporations: The Industrial Economics of Foreign Investment, Economica 38, 1-27.

Caves, Richard E. (1996), Multinational Enterprise and Economic Analysis. London: Cambridge University Press, second edition.

Cushman, David O. (1985), "Real Exchange Rate Risk, Expectations, and the Level of Direct Investment", Review of Economics and Statistics 32, 297-308.

Davis, Donald R. and David E. Weinstein (1998), "An Account of Global Factor Trade," manuscript.

Denekamp, Johannes and Michael J. Ferrantino (1990), "Substitution and Complementarity of U.S. Exports and Foreign Affiliate Sales in a Demand-Based Gravity System," manuscript, Southern Methodist University.

Eaton, Jonathan and Akiko Tamura (1994), "Bilateralism and Regionalism in Japanese and US Trade and Direct Foreign Investment", Journal of the Japanese and International Economics 8, 478-510.

Egger, Peter (1999?), "European Exports and Outward Foreign Direct Investment: A Dynamic Panel Data Approach," manuscript, Austrian Institute of Economic Research.

Ekholm, Karolina (1997), "Factor Endowments and the Pattern of Affiliate Production by Multinational Enterprises", CREDIT working paper no. 97/19, University of Nottingham.

Ekholm, Karolina (1998a), "Headquarter Services and Revealed Factor Abundance", Review of International Economics 6, 545-553.

Ekholm, Karolina (1998b), "Proximity Advantages, Scale Economies, and the Location of Production", in Braunerhjelm and Ekholm (editors), The Geography of Multinational Firms. Boston: Kluwer Academic Publishers.

Ekholm, Karolina and Rikard Forslid (1999), "Trade and Location with Horizontal and Vertical Multi-Region Firms", working paper.

Feinberg, Susan E. and Michael P. Keane (2001), "U.S.-Canada Trade Liberalization and MNC Production Location", Review of Economics and Statistics 83, 118-132. 
Ferrantino, Michael J. (1993), "The Effects of Intellectual Property Rights on International Trade and Investment", Weltwirtschaftliches Archiv 129, 300-331.

Goldberg, Linda S. and C.D. Kolstad (1995), "Foreign Direct Investment, Exchange-Rate Variability and Demand Uncertainty," International Economic Review 36, 855-873.

Greenaway, David, Peter Lloyd and Chris Milner (1998), "Intra-Industry FDI and Trade Flows: New Measures of Globalisation of Production", Centre for Research on Globalisation and Labour Markets research paper 98/5.

Grubert, Harry and John Mutti (1991), "Taxes, Tariffs and Transfer Pricing in Multinational Corporate Decision Making," Review of Economics and Statistics 73, 285-293.

Head, Keith and John Ries (2001), "Overseas Investment and Firm Exports," Review of International Economics 9, 108-122.

Head, Keith, John Ries, and Deborah Swenson (1995), "Agglomeration Benefits and Location Choice: Evidence from Japanese Manufacturing Investments in the United States," Journal of International Economics 38, 223-247.

Helpman, Elhanan (1984), "A Simple Theory of Trade with Multinational Corporations", Journal of Political Economy 92, 451-471.

Helpman, Elhanan (1985), "Multinational Corporations and Trade Structure", Review of Economic Studies 52, 443-58.

Helpman, Elhanan (1987), "Imperfect Competition and International Trade: Evidence from 14 Industrial Countries," Journal of the Japanese and International Economies 1, 62-81.

Helpman, Elhanan and Paul Krugman (1985), Market Structure and International Trade, Cambridge: MIT Press.

Horstmann, Ignatius J. and James R. Markusen (1987), "Strategic Investments and the Development of Multinationals", International Economic Review 28, 109-121.

Horstmann, Ignatius and James R. Markusen (1992), "Endogenous Market Structures in International Trade", Journal of International Economics 20: 225-247.

Jaffe, Adam B., Steven R. Peterson, Paul R. Portney, and Robert N.Stavins (1995), "Environmental Regulations and the Competitiveness of U.S. Manufacturing: What Does the Evidence Tell Us?" Journal of Economic Literature 33, 132-163.

Jones, Ronald W. (1971), "A Three-Factor Model in Theory, Trade, and History", in J. Bhagwati et. al. (eds.), Trade, Balance of Payments and Growth, Amsterdam: North-Holland. 
Kemp, Murray C. (1962), "Foreign Investment and the National Advantage", Economic Record $38,56-62$.

Lipsey, Robert E. (1991), "Foreign Direct Investment in the United States and U.S. Trade," The Annals of the American Academy of Political and Social Science no. 516, 76-90.

Lipsey, Robert E. (1999), "Affiliates of U.S. and Japanese Multinationals in East Asian Production and Trade", NBER working paper 7292.

Lipsey, Robert E., Magnus Blomstrom and Eric Ramstetter (1995), "Internationalized Production in World Output", NBER working paper 5385.

Lipsey, Robert E., Eric Ramstetter and Magnus Blomstrom (2000), "Outward FDI and Parent Exports and Employment: Japan, the United States, and Sweden", NBER working paper 7623.

Lipsey, Robert E. and Merle Yahr Weiss (1981), "Foreign Production and Exports in Manufacturing Industries," Review of Economics and Statistics 63, 488-494.

Lipsey, Robert E. and Merle Yahr Weiss (1984), "Foreign Production and Exports of Individual Firms," Review of Economics and Statistics 66, 304-307.

MacDougall, G.D.A (1960), "The Benefits and Costs of Private Investment from Abroad: A Theoretical Approach", Economic Record 36, 13-35.

Markusen, James R. (1984), "Multinationals, Multi-Plant Economies, and the Gains from Trade", Journal of International Economics 16, 205-226.

Markusen, James R. (1995), "The Boundaries of Multinational Enterprises and the Theory of International Trade", Journal of Economic Perspectives 9, 169-190.

Markusen, James R. (1997), "Trade versus Investment Liberalization", NBER working paper 6231.

Markusen, James R. (2001), Multinational Firms and the Theory of International Trade, Cambridge: MIT Press, forthcoming.

Markusen, James R. and Keith E. Maskus (2001a), "Multinational Firms: Reconciling Theory and Evidence", in Magnus Blomstrom and Linda Goldberg (editors), Topics in Empirical International Economics: A Festschrift in Honor of Robert E. Lipsey, Chicago: University of Chicago Press, forthcoming.

Markusen, James R. and Keith E. Maskus (2001b), "Discriminating among Alternative Theories of the Multinational Enterprise", revision of NBER working paper 7164, 1999. 
Markusen, James R. and Keith E. Maskus (2001c), "A Unified Approach to Intra-Industry Trade and Direct Foreign Investment", manuscript University of Colorado.

Markusen, James R. and Anthony J. Venables (1998), "Multinational Firms and the New Trade Theory", Journal of International Economics 46: 183-203.

Markusen, James R. and Anthony J. Venables (2000), "The Theory of Endowment, IntraIndustry and Multinational Trade", Journal of International Economics 52, 209-234.

Maskus, Keith E. (1998a), "The Role of Intellectual Property Rights in Encouraging Foreign Direct Investment and Technology Transfer", Duke Journal of Comparative and International Law 9, 109-161.

Maskus, Keith E. (1998b), "The International Regulation of Intellectual Property," Weltwirtschaftliches Archiv 134, 186-208.

Maskus, Keith E. and Alan Webster (1995), "Comparative Advantage and the Location of Inward Foreign Direct Investment: Evidence from the UK and South Korea," The World Economy, 18, 315-328.

Slaughter, Matthew J. (2000), "Production Transfer within Multinational Enterprises and American Wages", Journal of International Economics 50, 449-472.

Smith, Pamela J. (2001), "How Do Foreign Patent Rights Affect U.S. Exports, Affiliate Sales, and Licenses?" Journal of International Economics, forthcoming.

Swedenborg, Birgitta (1979), The Multinational Operations of Swedish Firms, Stockholm: The Industrial Institute for Economic and Social Research.

Swenson, Debra (1998), "The Tradeoff between Trade and Foreign Investment", University of California, Davis, working paper.

Trefler, Daniel (1995), "The Case of the Missing Trade and Other Mysteries," American Economic Review 85, 1029-1046.

United Nations Conference on Trade and Development (1996), Incentives and Foreign Direct Investment, Geneva: UNCTAD.

Wheeler, David and Ashoka Mody (1992), "International Investment Location Decisions: the Case of U.S. Firms", Journal of International Economics 33, 57-76.

Woodward, Douglas P. (1992), "Locational Determinants of Japanese Manufacturing Start-ups in the United States", Southern Economic Journal 58, 690-708. 


\section{Figure 1: Volume of affiliate production, KK model}

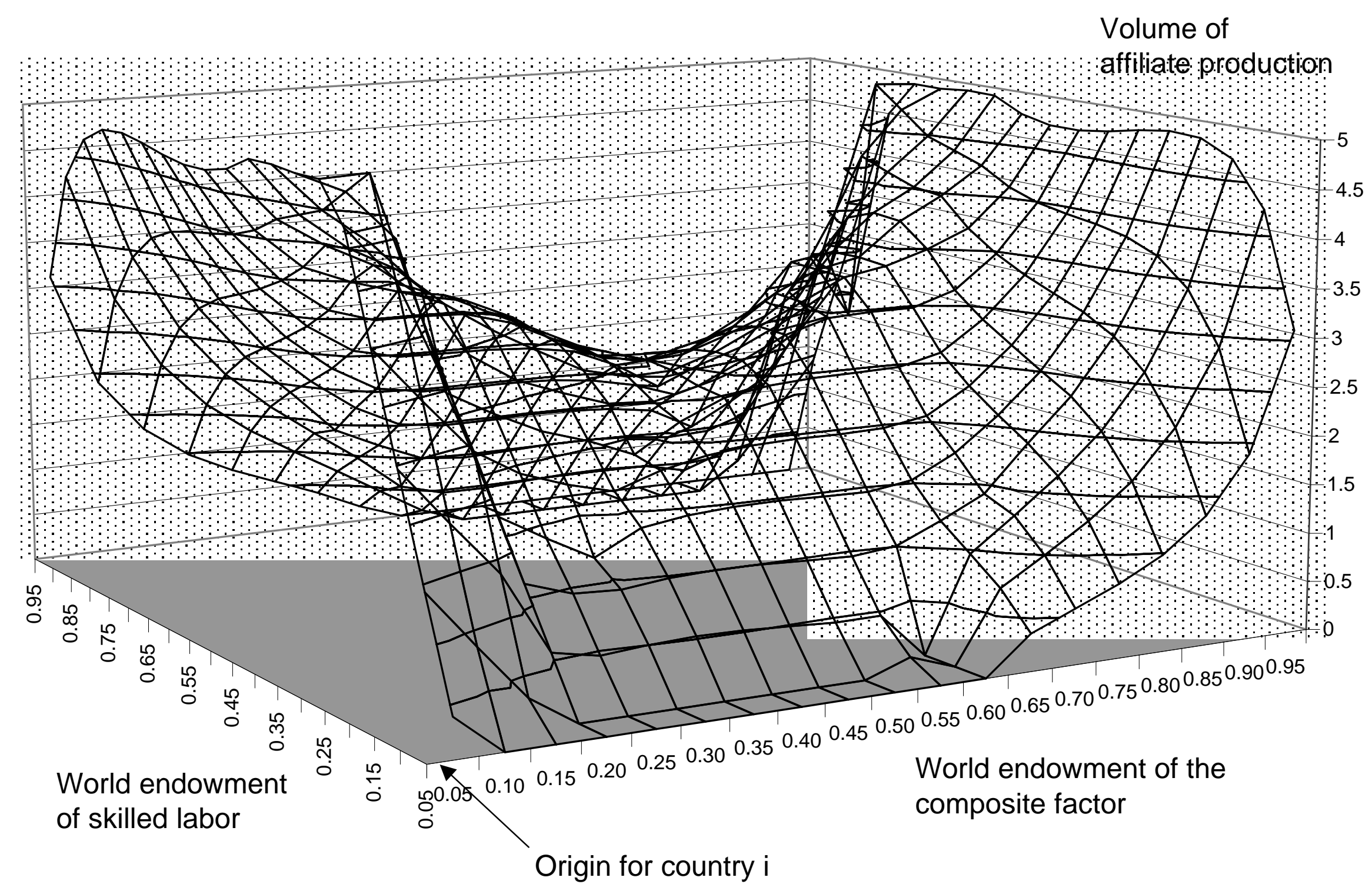


Figure 2: Volume of affiliate production, HOR model

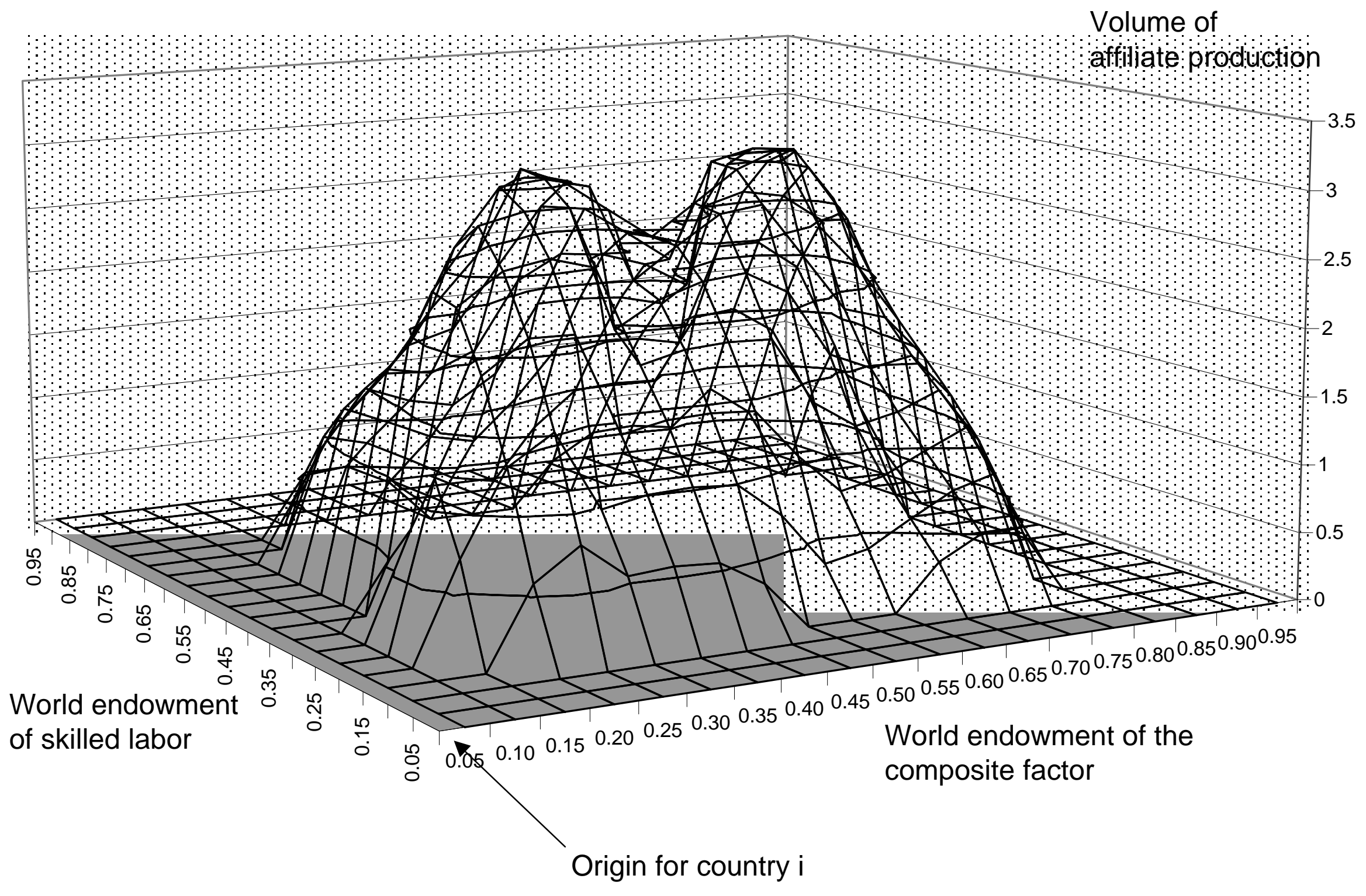




\section{Figure 3: Volume of affiliate production, VER model}

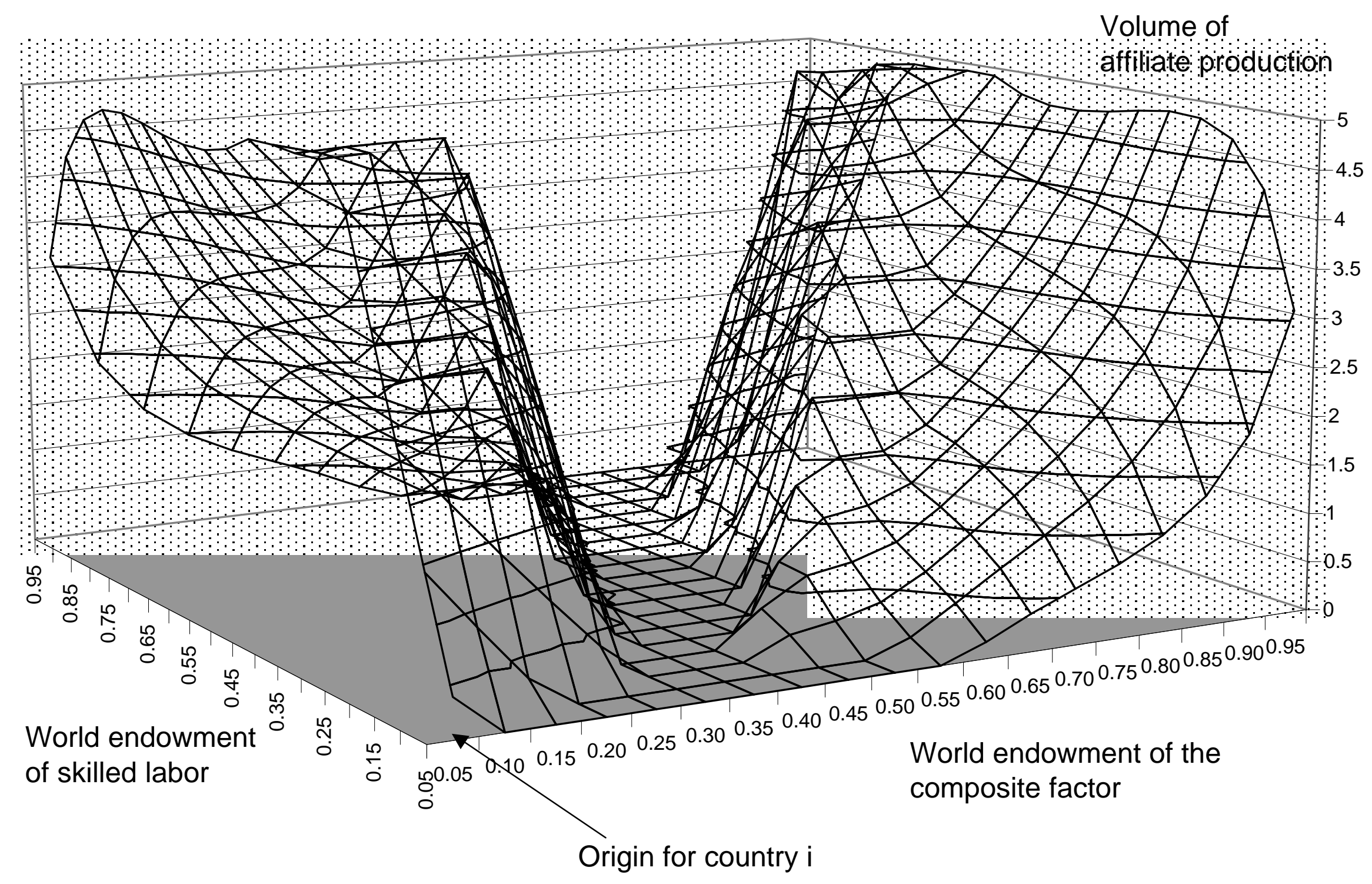




\section{Figure 4: Change in the volume of affiliate production: trade costs reduce from $20 \%$ to $1 \%$}

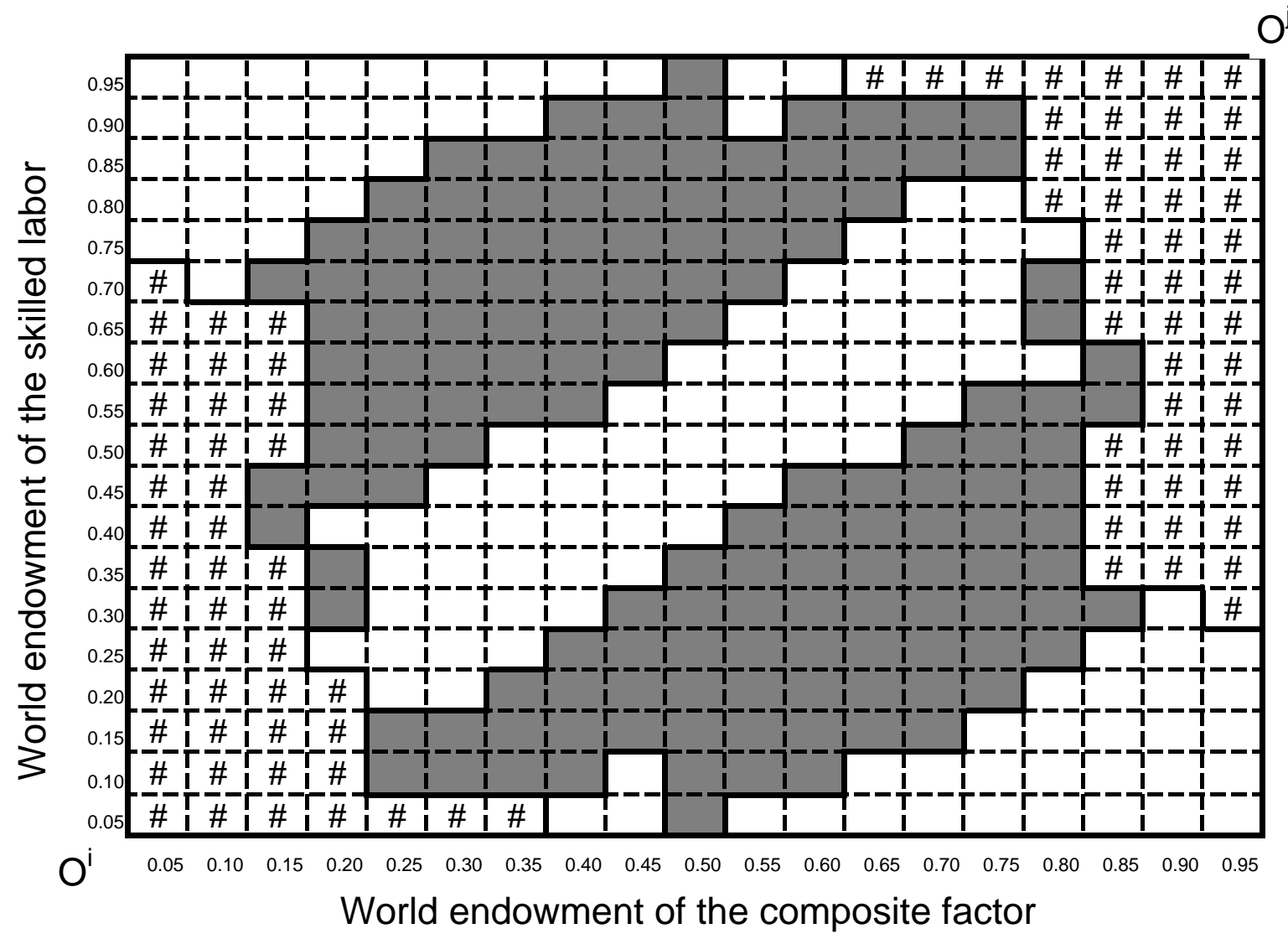

Volume of affiliate production falls

Volume of affiliate production increases

Volume of affiliate production constant 

Figure 5: Change in the volume of trade following investment liberalization, high trade costs $(20 \%)$

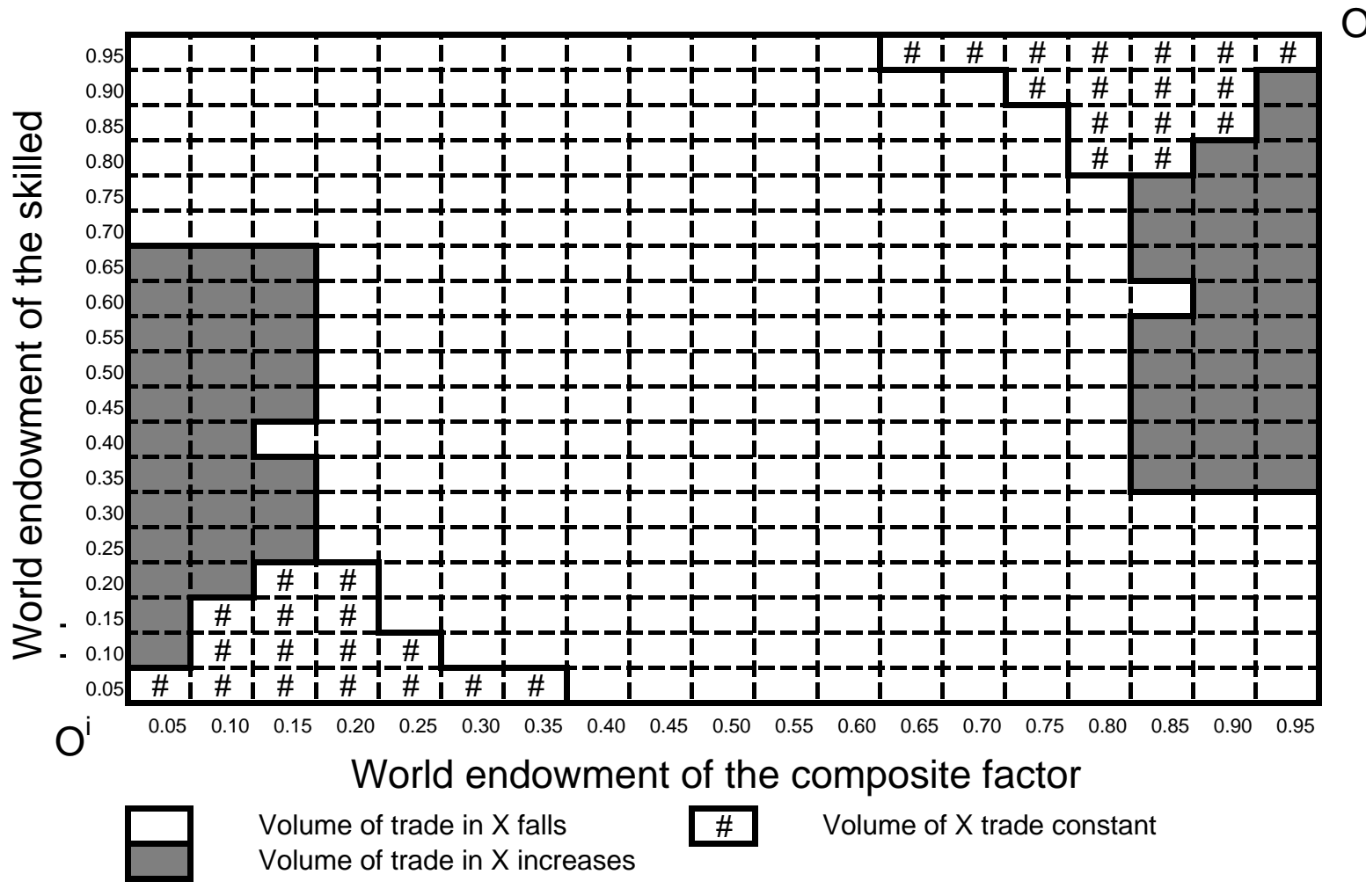

\section{Figure 6: Change in the volume of trade following investment liberaliztion, low trade costs (1\%)}

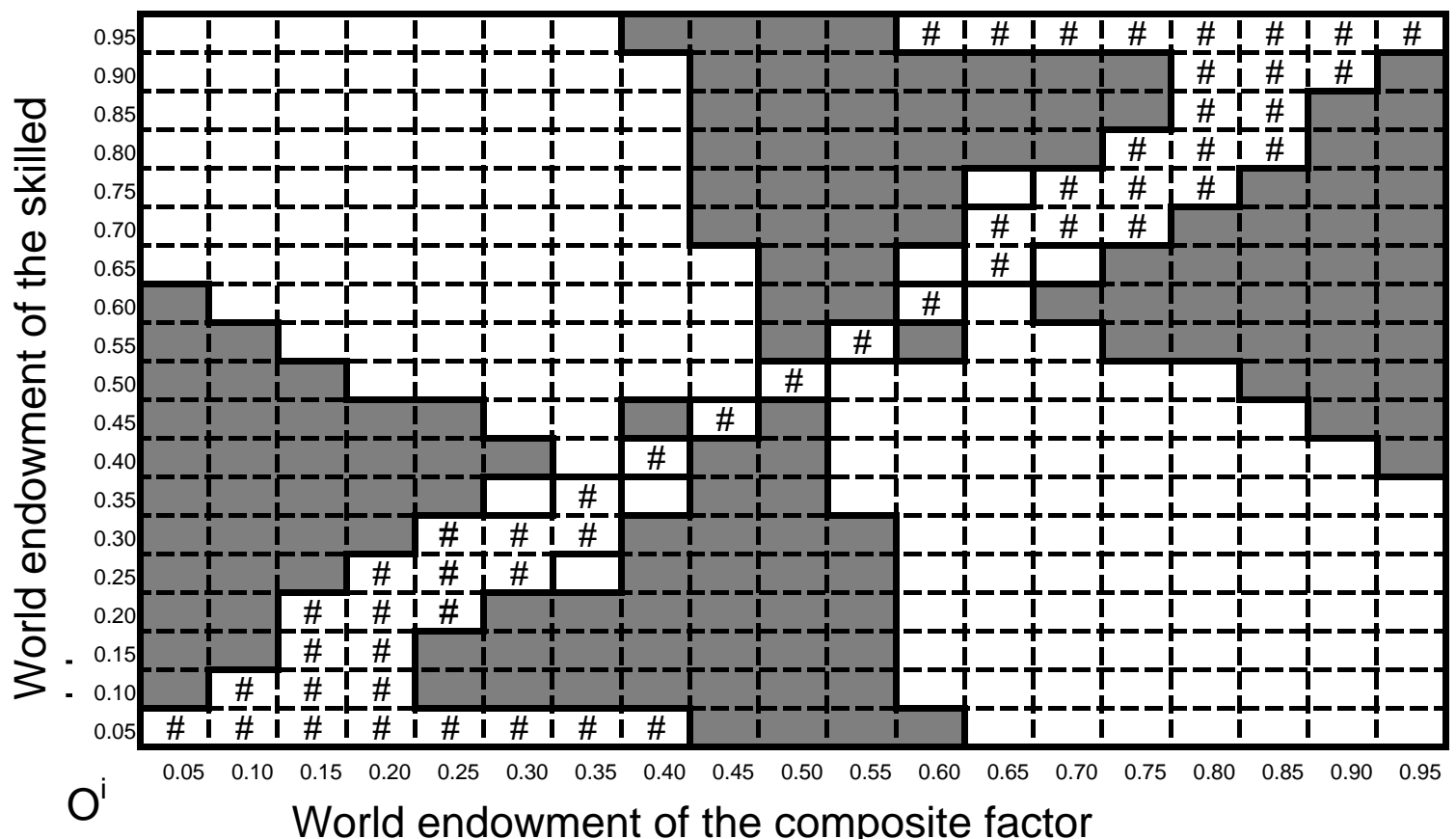

